\title{
Epidemiology of osteoporotic fractures in Brazil: what we have and what we need
}

\author{
Epidemiologia de fraturas pela osteoporose no \\ Brasil: o que temos e o que precisamos
}

Marcelo de Medeiros Pinheiro', Sérgio Ragi Eis²

\begin{abstract}
1 Médico-assistente e coordenador da Clínica de Doenças Osteometabólicas e do Serviço de Densitometria Óssea, Disciplina de Reumatologia, Escola Paulista de Medicina, Universidade Federal de São Paulo (Unifesp/ EPM), São Paulo, SP, Brasil 2 Investigador chefe e diretor médico, CEDOES Diagnóstico e Pesquisa, Vitória, ES. Diretor da Sociedade Internacional de Densitometria Clínica (ISCD) e da Sociedade Brasileira de Densitometria (SBDens), São Paulo, SP, Brasil
\end{abstract}

Correspondence to: Marcelo de Medeiros Pinheiro Av. Dr. Altino Arantes, 669, ap. 105 04042-033 - São Paulo, SP, Brasil mpinheiro@uol.com.br

Received on Dec/8/2009 Accepted on Mar/3/2010

\section{SUMMARY}

The epidemiology of osteoporotic fractures varies widely among countries and is primarily related to differences in the population and utilization of public healthcare services. Since 1994, over 200 studies about osteoporosis and fractures have been conducted in Brazil, among which 60 have described the current epidemiological status. This work is a compilation of studies published in scientific journals (PubMed, MedLine, Lilacs, SciELO Database) with the respective highlights. Overall, these studies show moderate incidence of hip fracture in subjects over 50 years old. However, the prevalence of all types of bone fragility fracture is higher, ranging from $11 \%$ to $23.8 \%$. In addition, there is a high incidence of recurrent falls, which are the main extraskeletal factor associated with these fractures. According to the national studies, 12 months after femoral fractures, the mortality rate ranged between $21.5 \%$ and $30 \%$, and there was also a high rate of physical impairment, deterioration of the quality of life and excessive burden to the healthcare system. Considering its high prevalence and associated mortality and physical impairment, osteoporosis and its main consequence, bone fragility fractures, must be considered a major public health problem in our country. Arq Bras Endocrinol Metab. 2010;54(2):164-70

\section{Keywords}

Epidemiology; fracture; osteoporosis; Brazil

\section{SUMÁRIO}

A epidemiologia das fraturas por osteoporose varia amplamente entre os países, principalmente em decorrência das diferenças entre as populações e da utilização de recursos públicos de saúde. Desde 1994, mais de 200 estudos sobre osteoporose e fraturas foram feitos no Brasil, dos quais 60 descreveram a situação epidemiológica atual. Esse manuscrito é a compilação de estudos publicados em revistas científicas (PubMed, MedLine, Lilacs, SciELO Database) com seus principais achados. Em geral, esses trabalhos mostram moderada incidência de fratura de quadril em indivíduos acima de 50 anos de idade. No entanto, a prevalência de todos os tipos de fratura por fragilidade óssea é elevada, variando de $11 \%$ a $23,8 \%$. Além disso, é observada alta incidência de quedas recorrentes, um dos principais aspectos extraesqueléticos associados com essas fraturas. De acordo com os estudos nacionais, 12 meses após a fratura de fêmur, a taxa de mortalidade variou de $21,5 \%$ a $30 \%$, com elevada taxa de incapacidade física, deterioração da qualidade de vida e grande impacto sobre o sistema de saúde. Diante da elevada prevalência, associação com mortalidade e incapacidade física, a osteoporose e sua principal consequência, a fratura por fragilidade óssea, deveriam ser consideradas um problema de saúde pública em nosso país. Arq Bras Endocrinol Metab. 2010;54(2):164-70

\section{Descritores}

Epidemiologia; fratura; osteoporose; Brasil 
$\mathrm{T}$ he incidence of osteoporotic fractures varies widely among countries and is primarily related to differences in the population and utilization of public healthcare services (Table 1). In Latin America, studies have shown a prevalence of hip fracture of 4 to 36.2 for every 10,000 people (1). However, little is known on the epidemiology of osteoporosis and bone fragility fractures in representative samples of the Brazilian population. From 1994 to October 2009, over 200 national osteoporosis studies have been conducted and published in reference scientific journals by PubMed, MedLine, Lilacs, SciELO Database, among which 60 specifically described the epidemiological status of these conditions.

Table 1. Annual hip fracture incidence for every 10,000 inhabitants among subjects over 50 in the international scenario

\begin{tabular}{lccc}
\hline City, Country & Year & Women & Men \\
\hline Oslo, Norway & $1996-1997$ & 118 & 44 \\
Rochester, United States & $1988-1989$ & 114 & 41 \\
Fune, Denmark & $1973-1975$ & 90 & 30 \\
Wessex, England & $1993-1995$ & 82 & 30 \\
Reikjavik, Iceland & $1990-1992$ & 69.7 & 35 \\
Geneva, Switzerland & 1991 & 65 & 16 \\
Picardy, France & 1987 & 44 & 18 \\
Hong Kong, China & 1991 & 42.8 & 27 \\
La Plata, Argentina & $1988-1989$ & 33 & 26 \\
Budapest, Hungary & 1992 & 31.6 & 25 \\
Beijing, China & $1988-1992$ & 9.6 & 10.7 \\
Siena, Italy & $1975-1985$ & 3 & 0.7 \\
\hline
\end{tabular}

Some regional studies in Brazil suggest low to moderate incidences of hip fractures in subjects over 50 years old (Table 2). The annual age-adjusted incidence rates in the cities of Porto Alegre - RS (2), Sobral - CE (3), and Fortaleza - CE (4) were approximately four times lower than that reported in Caucasian populations of the Northern hemisphere. However, in Marilia, SP, the incidence was higher, especially among women and subjects over $70(5)$.

BRAZOS (BRAZilian Osteoporosis Study) was the first epidemiological study conducted in a representative sample of Brazilian men and women over 40, with the purpose of estimating the prevalence and identifying the main clinical risk factors associated with lowimpact fractures and recurrent falls. Over 2,400 subjects $(70 \%$ women $)$ from all regions in Brazil, including urban and rural populations, and from all social and economic levels, were randomly assessed by means of
Table 2. Annual hip fracture incidence for every 10,000 inhabitants among subjects over 50 in Brazil

\begin{tabular}{lccc}
\hline Author/Year & Region & Women & Men \\
\hline Sisson de Castro, 1990-1992 (2) & Porto Alegre, RS & 20.2 & 10.5 \\
Castro da Rocha, 1996-2000 (3) & Sobral, CE & 20.7 & 8.9 \\
Silveira, 2001-2002 (4) & Fortaleza, CE & 27.5 & 13 \\
Komatsu, 1994-1995 (5) & Marília, SP & 50 & 18.7 \\
\hline
\end{tabular}

quantitative, personal household interviews. According to data from this piece of research, the prevalence of low-impact fractures (humerus, femur, spine, forearm and ribs) in subjects over 50 was $12.8 \%$ for men and $15.1 \%$ for women $(6)$.

A general study of the population of the state of Rio Grande do Sul showed a fracture prevalence of $28.3 \%$, predominantly of the upper limbs and feet. The fracture prevalence throughout life was $37.5 \%$ in men, resulting primarily from sports and recreational activities and $21.3 \%$ in women, particularly in association with falls at home. It is important to point out that all fractures were included in the study, and not only the lowimpact fractures (7).

The LAVOS (Latin American Vertebral Osteoporosis Study) was the first epidemiological study performed in Latin America to assess morphometric vertebral fractures and the main risk factors associated. Clark and cols. (8), when randomly assessing 1922 women over 50 from five Latin American countries (Argentina, Brazil, Colombia, Mexico and Porto Rico), found a prevalence of morphometric vertebral fractures (11.18; 95\% CI 9.23-13.4) similar to data from Beijing and some regions in Europe. Furthermore, there was no significant difference between countries, but vertebral deformities increased with age (from $6.9 \%$ at $50-59$ to $27.8 \%$ in women over $80, \mathrm{p}<0.001)$. Specifically in Brazil, the population studied showed a mean prevalence of $14.8 \%$ of morphometric vertebral fractures and $23.8 \%$ of nonvertebral fractures (excluding feet, hands, skull and those resulting from accidents or trauma), including hip (2.5\%) (8).

Lopes and cols. (9), when assessing 769 elderly subjects in the community, have also verified similar prevalence of morphometric vertebral fractures among women (16.7\%; 95\% CI 13.3-20.1). In men, the prevalence was $21.2 \%(95 \%$ CI 16.6-25.7\%) (9). On the other hand, Bandeira and cols. (10) found higher prevalence of vertebral fractures $(37 \%)$ in 627 postmenopausal women, of whom 9\% had Grade I and 10.9\% had Grade III. It is important to emphasize that this high 
prevalence may be justified by origin from the reference center of these women and not from the general population (10).

More recently, Pinheiro and cols. (11), when studying a large cohort (SAPOS - SAo Paulo Osteoporosis $S t u d y)$ including more than four thousand pre and postmenopausal women in metropolitan São Paulo found a history of bone fragility fracture in $11.5 \%$ of this population, with mean age at event of $65.5 \pm 10$ years. Vertebral fractures were reported by $6 \%$ of the women and nonvertebral fractures were reported by $86 \%$, including humerus, forearm, metacarpus, metatarsus, ribs and hips. Femur fractures were reported by $8 \%$ and a history of hip fracture after 50 years of age in first-degree relatives was reported by $15 \%$ of the women, particularly by those with previous fracture $(\mathrm{p}<0.001)(11)$.

\section{BONE DENSITY AND OSTEOPOROSIS}

The prevalence of osteopenia and osteoporosis shown in Brazilian studies is widely variable because of different sample sizes, eligibility criteria and methodologies (Table 3). Most of these studies used convenience samples and populations from tertiary health institutions. SAPOS cohort found osteoporosis in $33 \%$ of the women, according to bone densitometry findings (11).

Table 3. Low bone density prevalence according to Brazilian studies

\begin{tabular}{lccc}
\hline Population & Osteopenia & Osteoporosis & Author \\
\hline Premenopausal & $22 \%$ & $6 \%$ & Martini and cols. (13) \\
Postmenopausal & $38 \%$ to $56.6 \%$ & $14.7 \%$ to $43.4 \%$ & Lanzillotti and cols. (14) \\
& $30 \%$ & $33 \%$ & Martini and cols. (13) \\
Men & $33.6 \%$ & $33.8 \%$ & Clark and cols. (8) \\
Elderly & $44.6 \%$ & $15.4 \%$ & Zerbini and cols. (15) \\
Men & & & \\
Women & $33.3 \%$ to $57.4 \%$ & $6.4 \%$ to $16.1 \%$ & Rodrigues Camargo \\
\hline
\end{tabular}

The incidence of osteoporosis and osteopenia among women in the Brazilian sample of the epidemiological study LAVOS (8), recruited in metropolitan Vitória and Vila Velha, ES by randomized sample planning was $33.6 \%$ and $33.8 \%$, respectively, according to the densitometric criteria proposed by the World Health Organization in 1994 (12).

The national epidemiological study (BRAZOS) showed that $6 \%$ of the general adult population knew about the diagnosis of osteoporosis (6). However, since no bone densitometry scans were performed, this low prevalence is not likely to reflect the reality. Additionally, there was a high rate of low-impact fractures. Therefore, if we adopt the definition of osteoporosis (12) in which the diagnosis of established osteoporosis can be determined in the presence of low-impact fractures, we will have at least $12.8 \%$ of osteoporosis in men and $15.1 \%$ in women.

Martini and cols. (13), when analyzing data from VIGITEL (chronic diseases risk and protection factor surveillance by phone, a program under the Ministry of Health), described the prevalence of osteoporosis reported by 54,369 adult subjects, both male and female, from all the state capitals and the Federal District, as well as the main risk and protection factors associated. In 2006 , the frequency of osteoporosis reported was $4.4 \%$, predominantly among women ( $7 \%$ vs. $1.3 \%)$. Reports of osteoporosis increased significantly with age (from $5.2 \%$ between 45 and 54 to $32.7 \%$ in women over 65 ) (13). It is important to highlight that the data presented are approximate prevalence based only on the medical diagnosis of osteoporosis reported by the subjects, which is more representative of the access to healthcare services than of the actual prevalence of the disease.

\section{RISK FACTORS}

Overall, the clinical risk factors found in Brazilian studies $(6,8,11,13-16)$ are similar to those observed in the international scenario. The main clinical risk and protection factors associated with low bone density and bone fragility fractures, according to national data, are presented in Table 4.

Genetic and dietary factors have been associated with increased risk of osteoporosis and fractures. Some national studies have investigated the genetic polymorphism of collagen $1 \alpha \mathrm{l}$ (COLlAl) (17), a receptor of vitamin D (VDR) (18-21) and estrogen (ER $\alpha)$ (22), but did not demonstrate any significant association with bone density or fractures. The only national epidemiological study showing an association between dietary aspects and low-impact fractures was the BRAZOS study $(6,23)$ (Table 5).

Several recent works have pointed to a higher prevalence of hypovitaminosis D in all continents, genders, age ranges and social and economic levels. Hypovitaminosis D was also observed among noninstitutionalized elderly subjects in the city of São Paulo, especially during the winter and fall. Vitamin D deficiency occurred in $15.4 \%$ of patients, insufficiency in $41.9 \%$ and secondary hyperparathyroidism in 55\% (24), although the relationship between these conditions and the fractures was not investigated by the authors. 
Table 4. Clinical risk and protection factors associated with osteoporosis and fractures, according to main Brazilian studies

\begin{tabular}{|c|c|c|}
\hline Study & Osteoporosis & Fracture \\
\hline $\begin{array}{l}\text { BRAZOS (6) } \\
\text { Women }\end{array}$ & & $\begin{array}{l}\text { Risk: Advanced age, family } \\
\text { history of femur fracture, early } \\
\text { menopause, lack of physical } \\
\text { activity, lower quality of life, } \\
\text { high phosphorus } \\
\text { consumption, diabetes } \\
\text { mellitus, current use of } \\
\text { benzodiazepines and recurrent } \\
\text { falls within the previous year } \\
\text { Risk: Lower quality of life, } \\
\text { current use of tobacco, } \\
\text { diabetes mellitus and lack of } \\
\text { physical activity }\end{array}$ \\
\hline LAVOS (8) & & $\begin{array}{l}\text { Risk: reported loss of height } \\
\text { and previous fracture } \\
\text { Protection: hormone } \\
\text { replacement therapy and } \\
\text { physical activity }\end{array}$ \\
\hline $\begin{array}{l}\text { Lopes and } \\
\text { cols. (9) } \\
\text { Women } \\
\text { Men }\end{array}$ & & $\begin{array}{l}\text { Risk: age and femur neck bone } \\
\text { density } \\
\text { Risk: recurrent falls and femur } \\
\text { neck bone density }\end{array}$ \\
\hline SAPOS (11) & $\begin{array}{l}\text { Risk: advanced age, } \\
\text { menopause, previous fracture } \\
\text { and current use of tobacco } \\
\text { Protection: high BMI, regular } \\
\text { physical activity and current } \\
\text { hormone replacement } \\
\text { therapy }\end{array}$ & $\begin{array}{l}\text { Risk: advanced age, } \\
\text { menopause, family history of } \\
\text { hip fracture and low bone } \\
\text { density } \\
\text { Protection: regular physical } \\
\text { activity }\end{array}$ \\
\hline VIGITEL (13) & $\begin{array}{l}\text { Risk: age over } 45 \text { and use of } \\
\text { tobacco }\end{array}$ & \\
\hline Women & $\begin{array}{l}\text { Protection: higher education } \\
\text { level, non-Caucasian, regular } \\
\text { consumption of milk, green } \\
\text { and yellow vegetables }\end{array}$ & \\
\hline Men & $\begin{array}{l}\text { Risk: age over } 65 \text { and lack of } \\
\text { physical activity }\end{array}$ & \\
\hline
\end{tabular}

SAPOS: SAo Paulo Osteoporosis Study; BRAZOS: BRAZilian Osteoporosis Study; LAVOS: Latin America Vertebral Osteoporosis Study; VIGITEL: Chronic diseases risk and protection factors surveillance by phone.

Falls

As the population ages, falls represent an ever increasing impact on the public healthcare system. Approximately $30 \%$ of the elderly fall every year and nearly half of them have recurrent events. However, the incidence of falls varies widely and depends on different parameters of the population under study, such as gender, age range, genetic factors, life habits and personal background. The individual impact of each of these parameters has not yet been fully described, but they can be cumulative and increase the risk of serious and tragic outcomes in the lives of the elderly, particularly cranioencephalic trauma, hospitalization, institutionalization, fractures and death.
Table 5. Daily intake of nutrients associated with bone health, according to the presence of low-impact fracture

\begin{tabular}{|c|c|c|c|c|}
\hline \multirow{3}{*}{$\begin{array}{l}\text { Daily dietary } \\
\text { intake }\end{array}$} & \multicolumn{4}{|c|}{ Bone fragility fracture } \\
\hline & \multicolumn{2}{|c|}{ No } & \multicolumn{2}{|c|}{ Yes } \\
\hline & Men & Women & Men & Women \\
\hline Energy (kcal) & $\begin{array}{c}1331^{\mathrm{a}} \\
(610-3098)\end{array}$ & $\begin{array}{c}1197 \\
(427-3565)\end{array}$ & $\begin{array}{c}1199 \\
(405-5128)\end{array}$ & $\begin{array}{c}1331 \\
(610-3098)\end{array}$ \\
\hline Protein (g) & $\begin{array}{c}62 \\
(51-73)\end{array}$ & $\begin{array}{c}59 \\
(49-68)\end{array}$ & $\begin{array}{c}66 \\
(50-76)\end{array}$ & $\begin{array}{c}60 \\
(53-71)\end{array}$ \\
\hline Calcium (mg) & $\begin{array}{c}359 \\
(255-503)\end{array}$ & $\begin{array}{c}372 \\
(276-518)\end{array}$ & $\begin{array}{c}382 \\
(263-545)\end{array}$ & $\begin{array}{c}414^{*} \\
(296-591)\end{array}$ \\
\hline $\begin{array}{l}\text { Phosphorus } \\
\text { (mg) }\end{array}$ & $\begin{array}{c}737 \\
(632-871)\end{array}$ & $\begin{array}{c}730 \\
(640-848)\end{array}$ & $\begin{array}{c}760 \\
(665-882)\end{array}$ & $\begin{array}{c}772^{\star} \\
(662-934)\end{array}$ \\
\hline Magnesium (mg) & $\begin{array}{c}201 \\
(161-245)\end{array}$ & $\begin{array}{c}189 \\
(158-223)\end{array}$ & $\begin{array}{c}244 \\
(159-244)\end{array}$ & $\begin{array}{c}196^{\star} \\
(164-235)\end{array}$ \\
\hline Vitamin D $(\mu \mathrm{g})$ & $\begin{array}{c}1,8 \\
(0,8-2,9)\end{array}$ & $\begin{array}{c}1,9 \\
(1,1-3,2)\end{array}$ & $\begin{array}{c}1,6 \\
(0,9-3,1)\end{array}$ & $\begin{array}{c}2,2 \\
(1,2-3,6)\end{array}$ \\
\hline Vitamin K ( $\mu \mathrm{g})$ & $\begin{array}{c}41 \\
(29-64)\end{array}$ & $\begin{array}{c}43 \\
(34-74)\end{array}$ & $\begin{array}{c}42 \\
(29-75)\end{array}$ & $\begin{array}{c}39 \\
(31-71)\end{array}$ \\
\hline $\begin{array}{l}\text { Vitamin A ( } \mu \mathrm{g} \\
\text { REA) }\end{array}$ & $\begin{array}{c}131 \\
(18-265)\end{array}$ & $\begin{array}{c}138 \\
(68-257)\end{array}$ & $\begin{array}{c}212 \\
(116-335)\end{array}$ & $\begin{array}{c}231 \\
(141-376)\end{array}$ \\
\hline
\end{tabular}

a median (minimum-maximun). REA: retinol equivalent activity. * Oneway ANCOVA, adjusted for age and use of nutritional supplements, $p<0.05$ male vs. female with fracture.

Falls are associated with vertebral and non-vertebral fractures, especially of the hips, regardless of bone density. The combination of risk factors, bone density and falls is relevant for determination of the individual fracture risk of each patient, and also increases the sensitivity and specificity of instruments used for identifying subjects with fractures in population studies. The strategies currently used to prevent osteoporotic fractures must fully contemplate these aspects.

In Brazil, the prevalence of recurrent falls within the previous 12 months may vary from $10 \%$ to $40 \%(25-33)$ (Table 6$)$. The prevalence may also vary according to the region (30) (Figure 1). Overall, the incidence of recurrent falls among subjects in the South is lower than that among subjects in other regions. Recurrent falls among men from rural regions is significantly higher than in metropolitan areas (16.3 and 13.1, respectively). However, this finding was not observed among women $(24.5 \%$ and $25.5 \%$, respectively).

The main clinical risk factors associated with falls identified in Brazilian studies were dementia (25), delirium (26), current use of calcium channel blockers, benzodiazepines $(27,28)$, physical household environment (29), advanced age, regular alcohol consumption, lower quality of life, previous fracture, diabetes mellitus, lower dietary consumption of vitamin D and lack of physical activity (30). 
Table 6. Prevalence of falls, according to the results of Brazilian studies

\begin{tabular}{lccc}
\hline Author/Year & City & $\begin{array}{c}\text { Falls } \\
\text { within the } \\
\text { previous } \\
\mathbf{1 2} \\
\text { months }\end{array}$ & $\begin{array}{c}\text { Recurrent } \\
\text { falls } \\
\text { within the } \\
\text { previous } \\
\text { year }\end{array}$ \\
\hline Chaimowicz and cols., 2000 (27) & Belo Horizonte & $17 \%$ & - \\
Perracini and Ramos, 2002 (31) & São Paulo & $29 \%$ & $12 \%$ \\
Schwartz and cols., 1999 (32) & São Paulo & $29 \%$ & $12.2 \%$ \\
Rozenfeld and cols., 2003 (33) & Rio de Janeiro & $37 \%$ & $14 \%$ \\
Pinheiro and cols., 2008 (30) & Brazil & & \\
& Men & $27.1 \%$ & $15.5 \%$ \\
& Women & $32.8 \%$ & $25.6 \%$ \\
\hline
\end{tabular}

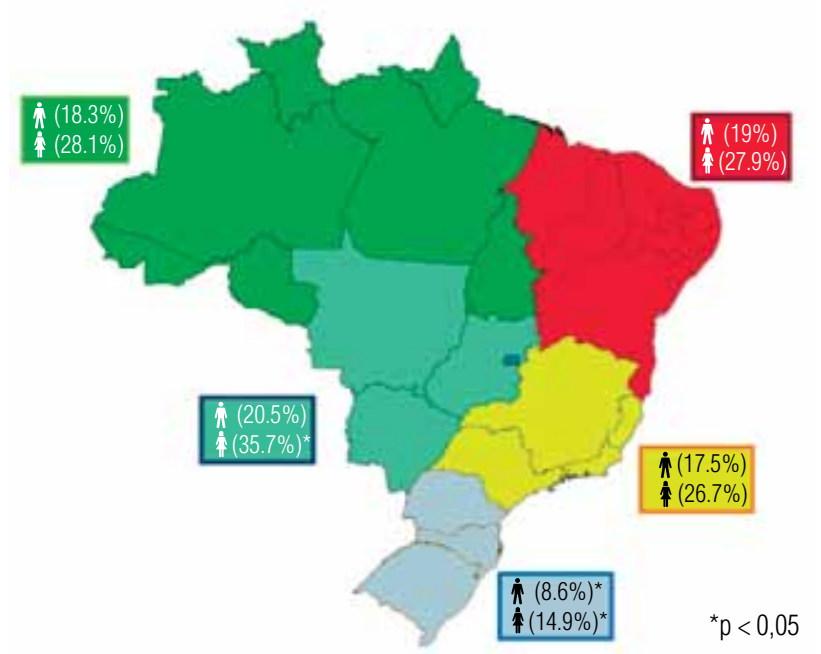

Figure 1. Frequency distribution of falls referred by Brazilian men and women over 40 years old by region.

\section{Mortality}

It is known that $15 \%$ to $30 \%$ of the patients with hip fractures die during the first year after the event, usually due to fracture complications such as infection, venous thrombosis and pressure ulcers, or associated conditions, especially cardiovascular diseases. In addition, these patients have an increased risk of becoming dependent or institutionalized after the fracture. The main factors related to the increased risk of death in these subjects are related to male gender, advanced age, lower functional capacity before the event, higher number of concomitant diseases, sarcopenia and frail phenotype (34). A recent prospective cohort with a 5-year followup has shown clear association between lower bone mass and higher overall and cardiovascular mortality among elderly women, regardless of age, which suggests some similarity between vascular calcification and atherosclerosis with osteogenesis and osteoporosis (35).

In the first year after hip fractures, the overall mortality observed in a study performed in Rio de Janeiro was $21.5 \%$ (36). Most of deaths (55.1\%) occurred after medical discharge, especially due to cardiovascular events and infections (37-38). Recently, Fortes and cols. (39) showed a mortality rate of $23.2 \%$ after 6-month follow-up of hip fractures in 56 elderly patients. Furthermore, they showed that only $30 \%$ of patients were able to return to their previous activities and $11.6 \%$ became completely dependent (39).

\section{Quality of life}

Osteoporosis has a significant deleterious impact on the quality of life of patients, particularly after bone fragility fractures. However, the study conducted by Cantarelli and cols. (40) did not demonstrate deterioration of the quality of life as assessed by OPAQ (Osteoporosis Assessment Questionnaire) in elderly women with osteoporosis or low-impact fractures (40).

On the other hand, Lemos and cols. (41) found a significant correlation between general (SF-36, The Medical Outcomes Study 36 - Item Short Form Health Survey) and specific (OPAQ) quality of life questionnaires applied to 40 women with postmenopausal osteoporosis, especially for pain, social aspects and mental health domains (41).

\section{Costs}

Osteoporosis-related costs vary widely among different countries, not only due to different incidence rates of the disease but also to the emphasis placed on prevention, hospitalization and treatment. Among postmenopausal women with osteoporosis, the utilization of health resources and the annual osteoporosis treatment costs were equivalent to 775 dollars per patient, and the drug-related costs required $9 \%$ of the monthly family income (42). Direct costs with hospitalization for osteoporotic hip fractures in subjects over 50 admitted into private hospitals were 12 thousand dollars, mainly related to medical and surgical instrumentation (61\%). Femur fractures were observed in $4.99 \%$ of the total 129,611 osteoporosis cases managed by the national supplementary healthcare system, with a mean stay of 9.21 days. The annual economic impact of these fractures for health insurance companies was estimated at approximately 6 million dollars (43). Although extremely relevant, these findings do not provide consistent inputs about total mid-term and long-term costs. In Latin America, including São Paulo, direct costs of hip fractures range between 4.5 and 6 thousand dollars (1). 


\section{FINAL CONSIDERATIONS AND CONCLUSION}

An important strategy for implementation of health education and promotion-related measures is to know the prevalence, incidence and specific risk factors of the Brazilian population. Particularly, in Brazil, the main clinical risk factors associated with osteoporotic fractures were not known and were usually extrapolated from European and American studies. In view of the studies presented, the identification and inclusion of these risk factors in routine medical practice may facilitate evaluation of the risk of fractures as well as individualized decision-making.

Using a combination of clinical risk factors and bone density measurements, Kanis and cols. (44) have recently proposed the use of FRAX ${ }^{\mathrm{TM}}$ as an objective and useful tool for quantification of the likelihood of fractures within the following 10 years, which directly impacts the decision-making process and the osteoporosis-related costs (44). However, calculation of the absolute risk of fractures depends on the population studied, and the use of this tool has not yet been approved in Brazil, once there is no reference database available (45).

Despite the many treatments available for prevention and management of osteoporosis, with effective reduction of vertebral (50\% to $65 \%$ ) and non-vertebral (25\% to $40 \%$ ) fractures, most of the Brazilian population still has no access to early diagnosis or appropriate therapeutics for the disease $(34,39,46)$. Practical measures for minimization of the risk of fractures can be easily implemented by a multidisciplinary team of physicians, physical educators, nutritionists, physical therapists and psychologists.

Considering its high prevalence and associated mortality and physical impairment, osteoporosis and its main consequence, bone fragility fractures, must be considered a major public health problem in our country. Public health policies must consider the results of the national studies presented before establishing prevention measures and strategies for early management of the disease as well as for utilization and allocation of financial resources, with a view to minimize the direct and indirect costs related to osteoporotic fractures.

In order to prepare the country for the economic and social costs that will be and have been imposed by osteoporosis on the Brazilian society, additional prospective epidemiological data is required, among other data, to allow assessment of the impact of each of the risk factors identified in our population as determinants of the incidence of different types of fractures. This will allow a better pharmacoeconomic understanding of the treatments currently approved for osteoporosis in our society. We will also be able to define intervention criteria based on the absolute risk of fractures. A group of Brazilian investigators and experts are currently designing a broad epidemiological study of osteoporosis and bone fragility fractures to provide the country with such relevant information.

Disclosure: no potential conflict of interest relevant to this article was reported.

\section{REFERENCES}

1. Morales-Torres J, Gutiérrez-Ureña S; Osteoporosis Committee of Pan-American League of Associations for Rheumatology. The burden of osteoporosis in Latin America. Osteoporos Int. 2004;15(8):625-32.

2. Schwartz AV, Kelsey JL, Maggi S, Tuttleman M, Ho SC, Jónsson $P V$, et al. International variation in the incidence of hip fractures: cross-national project on osteoporosis for the World Health Organization Program for Research on Aging. Osteoporos Int. 1999;9(3):242-53.

3. Castro da Rocha FA, Ribeiro AR. Low incidence of hip fractures in an equatorial area. Osteoporos Int. 2003;14(6):496-9.

4. Silveira VA, Medeiros MM, Coelho-Filho JM, Mota RS, Noleto JC, Costa FS, et al. Hip fracture incidence in an urban area in Northeast Brazil. Cad Saude Publica. 2005;21(3):907-12.

5. Komatsu RS, Ramos LR, SzejnfeldVL. Incidence of proximal femur fractures in Marilia, Brazil. J Nutr Health Aging. 2004;8(5):362-7.

6. Pinheiro MM, Ciconelli RM, Martini LA, Ferraz MB. Clinical risk factors for osteoporotic fractures in Brazilian women and men: The BRAZilian Osteoporosis Study (BRAZOS). Osteoporos Int. 2009;20(3):399-408.

7. Siqueira FV, Facchini LA, Hallal PC. The burden of fractures in Brazil: a population-based study. Bone. 2005;37(2):261-6.

8. Clark P, Cons-Molina F, Deleze M, Ragi S, Haddock L, Zanchetta JR, et al. The prevalence of radiographic vertebral fractures in Latin American countries: the Latin American Vertebral Osteoporosis Study (LAVOS). Osteoporos Int. 2009;20(2):275-82.

9. Lopes JB, Danilevicius CF, Takayama L, Caparbo VF, Menezes PR, Scazufca $M$, et al. Prevalence and risk factors of radiographic vertebral fracture in Brazilian community-dwelling elderly. Osteoporos Int. 2010. [In press]

10. Bandeira F, Carvalho EF. Prevalence of osteoporosis and vertebral fractures in postmenopausal women attending reference centers. Rev Bras Epidemiol. 2007;10(1):86-98.

11. Pinheiro MM, Reis Neto ET, Yang JHK, Machado FS, Omura F, Szejnfeld J, et al. Risk factors for osteoporotic fractures and low bone density in pre and postmenopausal women:The SAo Paulo Osteoporosis Study (SAPOS). Rev Saude Publica. 2010. [In press]

12. Kanis JA. Assessment of fracture risk and its application to screening for postmenopausal osteoporosis: synopsis of a WHO report. WHO Study Group. Osteoporos Int. 1994;4(6):368-81.

13. Martini LA, Moura EC, Santos LC, Malta DC, Pinheiro MM. Prevalência de diagnóstico auto-referido de osteoporose, Brasil, 2006. Rev Saude Publica. 2009;43(Supl 2):107-16.

14. Lanzillotti HS, Lanzillotti RS, Trotte APR, Dias AS, Bornand B, Costa EAMM. Osteoporosis in postmenopausal women, dietary calcium and other risk factors. Rev Nutr. 2003;16(2):181-93. 
15. Zerbini CA, Latorre MR, Jaime PC, TanakaT, Pippa MG. Bone mineral density in Brazilian men 50 years and older. Braz J Med Biol Res. 2000;33(12):1429-35.

16. Camargo MB, Cendoroglo MS, Ramos LR, Oliveira Latorre MR, Saraiva GL, Lage A, et al. Bone mineral density and osteoporosis among a predominantly Caucasian elderly population in the city of Sao Paulo, Brazil. Osteoporos Int. 2005;16(11):1451-60.

17. Barros ER, Kasamatsu TS, Ramalho AC, Hauache OM, Vieira JG, Lazaretti-Castro M. Bone mineral density in young women of the city of Sao Paulo, Brazil: correlation with both collagen type I alpha 1 gene polymorphism and clinical aspects. Braz J Med Biol Res. 2002;35(8):885-93.

18. Lazaretti-Castro M, Duarte-de-Oliveira MA, Russo EM, Vieira JG. Vitamin $D$ receptor alleles and bone mineral density in a normal premenopausal Brazilian female population. Braz J Med Biol Res. 1997;30(8):929-32.

19. Hauache OM, Lazaretti-Castro M, Andreoni S, Gimeno SG, Brandao $C$, Ramalho $A C$, et al. Vitamin $D$ receptor gene polymorphism: correlation with bone mineral density in a Brazilian population with insulin-dependent diabetes mellitus. Osteoporos Int. 1998;8(3):204-10.

20. Ramalho AC, Lazaretti-Castro M, Hauache O, Kasamatsu T, Brandao $C$, Reis $A F$, et al. Fractures of the proximal femur: correlation with vitamin D receptor gene polymorphism. Braz J Med Biol Res. 1998;31(7):921-7.

21. Heilberg IP, Teixeira SH, Martini LA, Boim MA. Vitamin D receptor gene polymorphism and bone mineral density in hypercalciuric calcium-stone-forming patients. Nephron. 2002;90(1):51-7.

22. Heilberg IP, Hernandez E, Alonzo E, Valera R, Ferreira LG, Gomes $A S$, et al. Estrogen receptor (ER) gene polymorphism may predict the bone mineral density response to raloxifene in postmenopausal women on chronic hemodialysis. Ren Fail. 2005;27(2):155-6.

23. Pinheiro MM, Jacques NO, Genaro PS, Ciconelli RM, Ferraz MB, Martini LA. Nutrient intakes related to osteoporotic fractures in Brazilian men and women - The Brazilian Osteoporosis Study (BRAZOS). Nutrition J. 2009;8:6.

24. Saraiva GL, Cendoroglo MS, Ramos LR, Araujo LM, Vieira JG, Kunii I, et al. Influence of ultraviolet radiation on the production of 25 hydroxyvitamin $D$ in the elderly population in the city of Sao Paulo (23 o 34'S), Brazil. Osteoporos Int. 2005;16(12):1649-54.

25. Carvalho AM, Coutinho ESF. Dementia as risk factor for severe bone fractures among the elderly. Rev Saude Publica. 2002;36(4):448-54.

26. Furlaneto ME, Garcez-Leme LE. Delirium in elderly individuals with hip fracture: causes, incidence, prevalence, and risk factors. Clinics. 2006;61(1):35-40.

27. Chaimowicz F, Ferreira TJ, Miguel DF. Use of psychoactive drugs and related falls among older people living in a community in Brazil. Rev Saude Publica. 2000;34(6):631-5.

28. Coutinho ESF, Silva SD. Medication as a risk factor for falls resulting in severe fractures in the elderly. Cad Saude Publica. 2002;18(5):1359-66.

29. Fabrício SC, Rodrigues RA, da Costa ML Jr. Falls among older adults seen at a São Paulo State public hospital: causes and consequences. Rev Saude Publica. 2004;38(1):93-9.
30. Pinheiro MM, Ciconelli RM, Martini LA, Ferraz MB. Risk factors for recurrent falls among Brazilian women and men:The Brazilian Osteoporosis Study (BRAZOS). Cad Saude Publica. 2010;26(1):89-96.

31. Perracini MR, Ramos LR. Fatores associados a quedas em uma coorte de idosos residentes na comunidade. Rev Saude Publica. 2002;36(6):709-16.

32. Schwartz AV, Villa ML, Prill M, Kelsey JA, Galinus JA, Delay RR, et al. Falls in older Mexican-American women. J Am Geriatr Soc. 1999;47(11):1371-8.

33. Rozenfeld S, Camacho LAB, Veras RP. Medication as a risk factor for falls in older women in Brazil. Rev Panam Salud Publica. 2003;13(6):369-75.

34. Pinheiro MM. Mortalidade após fratura por osteoporose. Arq Bras Endocrinol Metab. 2008;52(7):968-69.

35. Pinheiro MM, Castro CM, Szejnfeld VL. Low femoral bone mineral density and quantitative ultrasound are risk factors for new osteoporotic fracture and total and cardiovascular mortality: a 5-year population-based study of Brazilian elderly women. J Gerontol A Biol Sci Med Sci. 2006;61(2):196-203.

36. Vidal El, Coeli CM, Pinheiro RS, Camargo KR Jr. Mortality within 1 year after hip fracture surgical repair in the elderly according to postoperative period: a probabilistic record linkage study in Brazil. Osteoporos Int. 2006;17(10):1569-76.

37. Coutinho ES, Coeli CM. Accuracy of the probabilistic record linkage methodology to ascertain deaths in survival studies. Cad Saude Publica. 2006;22(10):2249-52.

38. Garcia R, Leme MD, Garcez-Leme LE. Evolution of Brazilian elderly with hip fracture secondary to a fall. Clinics. 2006;61(6):539-44.

39. Fortes EM, Raffaelli MP, Bracco OL, Takata ET, Reis FB, Santili C, et al. High morbid-mortability and reduced level of osteoporosis diagnosis among elderly people who had hip fractures in São Paulo City. Arq Bras Endocrinol Metab. 2008;52(7):1106-14.

40. Cantarelli FB, Szejnfeld VL, Oliveira LM, Ciconelli RM, Ferraz MB. Quality of life in patients with osteoporosis fractures: cultural adaptation, reliability and validity of the Osteoporosis Assessment Questionnaire. Clin Exp Rheumatol. 1999;17(5):547-51.

41. Lemos MCD, Miyamoto ST, Valim V, Natour J. Quality of life in patients with osteoporosis: correlation between OPAO and SF-36 Rev Bras Reumatol. 2006;46(5):323-28.

42. Kowalski SC, Szenjfeld VL, Ferraz MB. Resource utilization in postmenopausal osteoporosis without incident fractures. J Rheumatol. 2004;31(5):938-42.

43. Araujo DV, Oliveira JH, Bracco OL. Cost of osteoporotic hip fracture in the Brazilian private health care system. Arq Bras Endocrinol Metabol. 2005;49(6):897-901.

44. Kanis JA, on behalf of the World Health Organisation Scientific Group. http://www.shef.ac.uk/FRAX/reference.htm

45. Pinheiro MM, Camargos BM, Borba VZC, Lazaretti-Castro M. FRAX ${ }^{\mathrm{TM}}$ : Construindo uma idéia para o Brasil. Arq Bras Endocrinol Metab. 2009;53(6):783-90.

46. Szejnfeld VL, Jennings $F$, Castro CHM, Pinheiro MM, Lopes AC. Conhecimento dos médicos clínicos do Brasil sobre as estratégias de prevenção e tratamento da osteoporose. Rev Bras Reumatol. 2007;47(4):251-57. 